\begin{tabular}{|c|c|c|c|c|c|}
\hline RA (India) & $=3.117$ & SIS (USA) & $=0.912$ & ICV (Poland) & $=6.630$ \\
\hline SI (Dubai & 0.829 & РИНЦ (Russia) & $=0.156$ & PIF (India) & $=1.940$ \\
\hline IF (Australia) & $=0.56$ & ESJI (KZ) & $=8.716$ & IBI (India) & $=4.260$ \\
\hline $\mathbf{F}$ & $=1.500$ & SJIF (Morocco) & $=5.667$ & ОАJI (USA) & $=0.350$ \\
\hline
\end{tabular}

Impact Factor:

$\begin{array}{ll}\text { GIF (Australia) } & =\mathbf{0 . 5 6 4} \\ \mathbf{J I F} & =\mathbf{1 . 5 0 0}\end{array}$

SJIF $($ Morocco $)=\mathbf{5 . 6 6 7}$

SOI: $1.1 /$ TAS $\quad$ DOI: $10.15863 /$ TAS

International Scientific Journal Theoretical \& Applied Science

p-ISSN: 2308-4944 (print) e-ISSN: 2409-0085 (online)

Year: 2019 Issue: 03 Volume: 71

Published: $05.03 .2019 \quad \underline{\text { http://T-Science.org }}$
QR - Issue

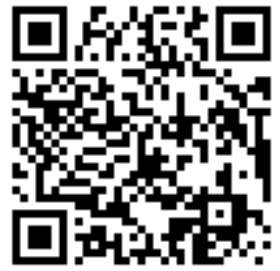

QR - Article

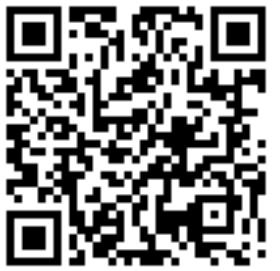

Nasriddin Nazarov

Doctor of Political Sciences, Professor of the National Institute of Fine Arts and Design named after Kamoliddin Behzod (Tashkent, Uzbekistan).

nasrid@mail.ru

\title{
SOME THEORETICAL ASPECTS OF INTERETHNIC RELATIONS TRANSFORMATION IN THE POLY-ETHNIC SOCIETY OF THE CENTRAL ASIA
}

\begin{abstract}
In this article the poly-ethnic community of the Central Asian region, the positive aspects of interethnic relations in this socio-cultural environment, i.e. the transformation of this process, have been studied on scientific and theoretical basis, and the challenges have been analyzed from a socio-philosophical point of view, focusing on paradigms that encourage transformation processes. Moreover, interethnic relations are considered as a philosophical category, and dialectical approach to this phenomenon has been analyzed by the factors serving to the national accord in the Central Asian region.

Key words: Central Asia, poly-ethnic society, interethnic relations, nation, ethnos, transformation, society, social philosophy, gnoseology, optimization.

Language: English

Citation: Nazarov, N. (2019). Some theoretical aspects of interethnic relations transformation in the polyethnic society of the Central Asia. ISJ Theoretical \& Applied Science, 03 (71), 420-424.

Soi: http://s-o-i.org/1.1/TAS-03-71-32 Doi: crossef https://dx.doi.org/10.15863/TAS.2019.03.71.32
\end{abstract}

\section{Introduction}

It is remarkable that the Central Asia, along with the creation and promotion of values of morality and spirituality of the region, embodies a great ethnosocial and cultural fragmentation of this multinational space. Diversity of ethnic and cultural demands, desires and needs of nations and ethnic groups that form the basis of this poly-ethnic society are differentiated, and the solution to these problems and needs constitutes the model of transformation of inter-ethnic relations in the region and indicates the optimal nature of transformation processes. Therefore, the study of theoretical aspects of the problem, examined as a regional model of the polytechnic community, sets the place of interethnic relations in the development of the Central Asia. Rationalism is the main paradigm of the theoretical approach in determining the problem solving on the basis of scientific and philosophical realities, which requires a reasonable and perceptible approach to interethnic relations.

\section{Materials and Methods}

The Central Asian republics have been living in peace and harmony for centuries thanks to the commonality of ethnic fate, the unity of the region, Islamic culture and the ethnic mentality of the nations, and these transnational, trade-economic and social relationships have been developing relative ties between our peoples. This, in turn, contributes to the development of mutual understanding in the region, as well as the transformation of this process as an important factor in raising the level of relations among the region's population.

Analysis of theories on nation-ethnos, based on the poly-ethnic essence of the region, in current conditions, when socio-political and cultural cooperation of the Central Asian republics is growing to a qualitatively new level:

Firstly, the socio-philosophical study of the theoretical foundations of interethnic relations, as well as contribution to the development of national science, will contribute to the strengthening of theoretical-methodological foundations of relations between the peoples of the region, promoting the growth of mutual relations and good neighborliness;

Secondly, at the current stage of formation of civil society institutions in the territory of the region's public societies, in contrast to the former Soviet system, ethnic and interethnic relations are not 


\begin{tabular}{|c|c|c|c|c|c|c|}
\hline \multirow{4}{*}{ Impact Factor: } & ISRA (India) & $=3.117$ & SIS (USA) & $=0.912$ & ICV (Poland) & $=6.630$ \\
\hline & ISI (Dubai, UAE & $=0.829$ & РИНЦ (Russia & $=0.156$ & PIF (India) & $=1.940$ \\
\hline & GIF (Australia) & $=0.564$ & ESJI (KZ) & $=8.716$ & IBI (India) & $=4.260$ \\
\hline & JIF & $=1.500$ & SJIF (Morocco & $=5.667$ & OAJI (USA) & $=0.350$ \\
\hline
\end{tabular}

based on classical-ideological perspective, but on universal principles and values based on democratic principles, taking into account the peculiarities of social and cultural factors, as the development of the national statehood and the growth of the process of national self-consciousness, a national ethno-cultural community is studying its past, along with ethnicity, historical, cultural and spiritual heritage of commonality, and its positive effects on the improvement of inter-ethnic relations, with a positive impact on the development of the unity and harmony;

Thirdly, studying the theoretical and methodological aspects of the interethnic relations based on the post-Soviet history, in particular the poly-ethnic nature of the Central Asian region, on the basis of today's vital realities, promoting analytical conclusions is crucial today in line with emerging civil society institutions, proposals and recommendations related to the role of ensuring the positive outcomes of socio-cultural development;

Fourthly, the essence of inter-ethnic relations, along with ethnos diversity and their subsequent progressive evolution, their role in the region's polytechnic community, and the role of sociocultural life in the theoretical perspective, the development of conceptual views, ethnicity, ethnic group, Diaspora, irredentist, interethnic relations, as well as the new stage of the process are evidences of transformation.

As for the inter-ethnic relations category, it is well known that "Relationship is a philosophical concept that expresses interrelationship between certain system elements" [1; P. 454]. Within the scope of this research, the system is a society and its elements are nation and ethnicity. The interrelationships between these elements are interpreted as interethnic relations that constitute the system and its essence, as well as the concept of interpersonal communication, solidarity or contradictions of different ethnicities. And this phenomenon, using a dialectical method, provides a gnoseological character for the study. "The dialectic method plays an important role in the methodology of studying the national relations and in the creation of the theory of nationality and inter-ethnic relations. This method involves the interconnection of events, their historical genesis, the occurrence and development of the phenomenon, the inclusion of all human experiences into the definition of the subject, the fact that abstract realities exist, and the truth is always clear" [2; P. 13]. The obvious fact in the problematic solution is that it is a gnoseologic approach that is crucial in the conceptual study of inter-ethnic relations.

From this point of view, interethnic relations are considered to be a socio-philosophical category, which is a combination of socio-political, cultural, economic and spiritual ties among representatives of different ethnics and ethnic groups, representing the interaction and behavior of the members of various nationalities. "The essence of inter-ethnic relations is that it is interconnected with intercultural dialogue, as well as institutional understanding of interethnic relationships" [3; P.4]. And this institutional essence of inter-ethnic relations requires a gnoseological approach to its study.

Interethnic relations are characterized by a socio-politically institutional level of functional character, interdisciplinary and inter-confessional, as well as a tendency toward relationships between groups of individuals and ethnic groups at the level of state and community organizations. Interrelationships between people of different ethnicities and ethno-social groups can be seen as a dynamically developing generator that stimulates interethnic relations and promotes certain aspects of this relationship. Thus individuals or groups of national minorities have a complete understanding of equality or inequality, discrimination or indiscrimination of rights, unity or disunity, which is considered in this subject as tolerance or tolerant; intolerance or inpatient; friendly; neutral; intolerant relationships or conflicts.

The process of inter-ethnic relations is also a social resource that reflects the characteristic features inherent in the nature of the period in each sociohistorical era. That is, the perception of a sociocultural and spiritual image of the period can be seen in interethnic relations - in the unity of nations or nationalities, or in contrast. True, in every sociohistorical era, the development of progress is accompanied by some or all of the characteristic problems that need to be addressed to ensure that these problems do not become social contradictions.

The multinational development policy in the context of the Central Asian region is multicultural development policy - especially for Uzbekistan, Kazakhstan and Kyrgyzstan. The Assembly of the Kazakh People's, which unites more than a hundred national cultural Centers in Kazakhstan, the Committee for the Interethnic Relations and Friendship Cooperation with Foreign Countries Coordinating more than hundred National Cultural Centers in Uzbekistan and the Assembly of peoples of Kyrgyzstan. Public associations within these socio-cultural associations seek to ensure multinational development through the development of culture, language, traditions and customs of nations and nationalities in the national-territorial units, indicating the transformation of inter-ethnic relations in the Central Asia. Indeed, raising civilian mentality through the development of national culture in the country, through the development of the culture of ethnic groups living in the amount from 120 to 140 nationalities in each national country of the region is an important step towards universal development. 


\begin{tabular}{|c|c|c|c|c|c|c|}
\hline \multirow{4}{*}{ Impact Factor: } & ISRA (India) & $=3.117$ & SIS (USA) & $=0.912$ & ICV (Poland) & $=6.630$ \\
\hline & ISI (Dubai, UAE & $=0.829$ & РИНЦ (Russia & $=0.156$ & PIF (India) & $=1.940$ \\
\hline & GIF (Australia) & $=0.564$ & ESJI (KZ) & $=8.716$ & IBI (India) & $=4.260$ \\
\hline & JIF & $=1.500$ & SJIF (Morocco & $=5.667$ & OAJI (USA) & $=0.350$ \\
\hline
\end{tabular}

In the poly-ethnic society, it is natural that there are problems in the area of inter-ethnic relations, but moral and ethical factors sometimes lead to such problems. Indeed, the aspirations for a solution to a particular problem will ensure progress. Otherwise, the stable situation will be resolved and the development will slow down. Problems are caused by objective and subjective factors. The objective factor is that the socio-political, economic, cultural and spiritual processes are incompatible with the interests of certain ethnic groups, and the subjective factor is the aggravation of the relationship between the representatives of some two ethnic groups, which can sometimes be traced back to individual circles and become a national essence. Problematic situations in the field of interethnic relations can occur in the following cases:

Firstly, in the poly-ethnic world, in the context of differences in the balance between the interests of a particular nation or the nation and the public, in the category of alienation, privatization and generalization (in general sense and in private sense);

Secondly, in a multinational society, the norms of relations between representatives of one nation or state and the second nationality or motherland (in private sense and among private interests) begin to worsen;

Thirdly, when the poly-ethnic community within a single society and the interests of the ruling state (in general and among common interests)

Fourthly, when the balance between the two cultures of different nationality or ethnicity is changed, this is sometimes disgusting by the national character (separately and among separate groups).

In order to avoid such negative moments, as we have already noted above among nations and ethnicities in the society, it is necessary to achieve a qualitative indicator of the culture of multiethnic inter-ethnic relations, the level of national tolerance.

Evolutionary process of inter-ethnic relations in the Central Asian region has a historical essence in the culture and the lifestyle of the people of the region on the basis of heritage dialectics. Unity and bloodshed in the process of universal ethno genesis, as well as for common progress, have been manifested in mutual relations, and never had a problematic situation with the peoples of the region, without the influence of the third force. At the end of the last century, the ethnic appearance of the old system was a manifestation of the problems on the socio-national backdrop, if we were to look at the ethnic identity of Alma-Ata, Osh, Meskhetian Turks and the events in Tajikistan. Osh events on the national ground of the year 2010 should be regarded as a contradiction that has been emerged by a third force.

Transformation processes in the poly-ethnic societies of the Central Asia are not smooth. Due to ethno-territorial properties, sometimes problems are also common. A. Pulatov, a Tajik scientist said: "The problem of nationalities and interethnic relations, especially of small nations, which do not have their own territorial state, has not been solved yet. One of the reasons why nationalism has worsened today in many countries is the problem that has not been addressed" [6; P. 29], as he said, indicating that interethnic relations in the Central Asian region are still some of the most pressing.

The Constitution, the Law, and the Government's Declaration of Tolerance, including the commitment to tolerance referring to other languages and cultures, are political and legal guarantees of interethnic relations and key elements of a socio-cultural guarantee.

The promotion of relations pursuing a gnoseological approach is the condition of positive perceptions and positive moods given the removing of negative stereotypes between the object and the subject or between the subject and the subject. Improving interethnic relations is an integral part of racial, social and cultural factors among national or ethnic groups, raising the sense of responsibility for friendship and common development in which the spirituality of a person is at the forefront.

In terms of interethnic relations, two things should be mentioned: the first is the relationship between ethnic groups and ethnic groups in a particular society, and, on the other hand, it is crucial to have a universal recognition as an expression of the real state of poly-ethnic inter-communal relations.

In terms of its application, interethnic relations are widely used in broad, medium and narrow meanings. In the broad sense, it is a social activity that is manifested by the interrelationships of various nations in the process of social, economic, political, national, cultural and spiritual activities, and in the medium sense - to one nation. In a narrow sense, it is evident in the relationships between individuals and ethnicities. However, any broad and medium perception of the sense of the word begins with a pronounced narrative. That is, interethnic relations are initially revealed in interpersonal communication and other communications. Especially, while the marriages between indigenous peoples are in the community, ethnicity is a key factor in developing relationships. Hence, the domestic relationships provide for the development of social relations. At the same time, any social relationships can be seen as a stimulus for promoting domestic relationships. Thus, the interconnection dialectic in inter-ethnic relations is manifested in the above example and identifies the transformation character of this process.

Interfaith culture is one of the leading positions in the development of interethnic relations, representing diverse ethnic groups. Indeed, this culture shapes tolerance that is crucial to ensuring 


\begin{tabular}{|c|c|c|c|c|c|c|}
\hline \multirow{4}{*}{ Impact Factor: } & ISRA (India) & $=3.117$ & SIS (USA) & $=0.912$ & ICV (Poland) & $=6.630$ \\
\hline & ISI (Dubai, UAE & $=0.829$ & РИНЦ (Russia & $=0.156$ & PIF (India) & $=1.940$ \\
\hline & GIF (Australia) & $=0.564$ & ESJI (KZ) & $=8.716$ & IBI (India) & $=4.260$ \\
\hline & JIF & $=1.500$ & SJIF (Morocco & $=5.667$ & OAJI (USA) & $=0.350$ \\
\hline
\end{tabular}

national peace in society. "... the culture of interethnic relations can also be characteristic of society, a separate social group or individual ... the criteria for the formation of the culture of interethnic relations among the persons are as follows:

- Awareness and attitude of the individual to national culture, history, religion, language and traditions;

- Awareness of the individual about the needs and interests of the nation and its attitude to them;

- The formation of national and universal values in a person;

- Attitude of a person to other national values and so on" [7; p. 4-5]

The above points can also be national selfidentification attributes. Thus, in the interethnic relations, a person or a national culture is closely linked to a person or a national identity. Undoubtedly, national self-consciousness is a necessary factor in maintaining the positive essence of inter-ethnic relations, as it does not see itself or its people as inferior to others.

The state of inter-ethnic relations is closely linked to ethno-social processes. Ethnic issues today are as follows: ethnic consolidation, inter-ethnic integration and assimilation. This process happens in every country in one place or another. Ethnic consolidation is an internal ethnic process characterized by ethnos self-development. Consolidation of nationalities, which are at the various stages of national self-consciousness, is important for the formation of national unity, which is characteristic of ensuring the positive development of the national relations, even if it is within one nation. Interethnic integration is the result of nations' complementary contribution and enrichment, and the core of the transformation of inter-ethnic relations. Internationalization assimilates the identity, language, customs and traditions of a particular nation, and embodies the bounds of national relations, even if it is inferior to other nationalities.

Inter-ethnic relations develop in three ways: low, medium and high. Its low visibility is the relationship that has arisen in the face of potential interethnic conflicts, while the middle one is a manifestation of national tolerance and national solidarity in society. High level of interethnic relations is the interaction between the two countries, not only at the level of one state, but also at the level of neighboring countries, to ensure optimal and harmonious nature of these relations. National harmony is a positive socio-political and cultural atmosphere of different ethnicities, as well as the relationship between different ethnic groups and ethnic groups within a particular achievement in a variety of issues on the basis of mutually beneficial cooperation, which provides the positive essence of transformational processes.
Improving interethnic relations is an effective tool of communication within the subjects of polyethnic relations as well as achieving effective methods of cooperation between nations and peoples, friendship and mutual support. It is well known that the study of the theoretical foundations of interethnic relations, analyzing improvement processes, promoting practical conclusions, and applying these conclusions to social life are a necessary factor for the positive development of the process. These are:

1. Ensure sustainable development in all societies and create conditions for the representatives of all nations and nationalities to pursue a common goal that is crucial to the improvement of interethnic relations;

2. Ethnic stability in social life is the key to the optimal development of national relations, it ensures the development of the culture, traditions and customs of nations and countries, which in turn promotes the cultural and ethical aspects of society based on social relationships and ensures its merits;

3. The solidarity in poly-ethic societies ensures a healthy environment in the society, and ensures progress. Considering the success of the activities of civil society institutions with the qualitative stages of social development, tolerance, unity and solidarity are more important nowadays than ever.

4. The analysis of real processes in social life shows that inter-ethnic relations among nations and ethnic groups are important to ensure the positive development of the process, as no progress in the improvement of cultural and ethical dimensions of interethnic relations is expected.

Ensuring the improvement of inter-ethnic relations is a multifaceted process, as well as interethnic relations in the society, with the constant attention of state and government. The following suggestions can be made to ensure the improvement of interethnic relations in the Central Asia and to ensure the positive nature of the transformation processes:

1. Along with the positive character of interethnic relations, it is necessary to lead this relationship in a certain direction, and to manage it. For this purpose, strengthening the activities of public and political organizations that coordinate the activities of national cultural centers and national societies, including promoting national culture and values, as well as promoting the positive aspects of cultures and enhancing their relationships with active participation of the activists of neighboring cultural centers should be maintained.

2. To explore and address societal inquiries in various fields of social life among representatives of multiethnic communities, members of multinational societies. It is important for the public opinion to be balanced with the country and public interest, as well as the ability to formulate public opinion, to develop it, to set goals, and to address the existing problems 


\begin{tabular}{|c|c|c|c|c|c|c|}
\hline \multirow{4}{*}{ Impact Factor: } & ISRA (India) & $=3.117$ & SIS (USA) & $=0.912$ & ICV (Poland) & $=6.630$ \\
\hline & ISI (Dubai, UAE & $=0.829$ & РИНЦ (Russia & $=0.156$ & PIF (India) & $=1.940$ \\
\hline & GIF (Australia) & $=0.564$ & ESJI (KZ) & $=8.716$ & IBI (India) & $=4.260$ \\
\hline & JIF & $=1.500$ & SJIF (Morocco & $=5.667$ & OAJI (USA) & $=0.350$ \\
\hline
\end{tabular}

and shortcomings identified in the survey, nationally and socially.

3. It is natural that problems in the field of interethnic relations are reflected in all areas of social life, and at first it may be problematic. In such a situation, it is necessary to ensure the solution of socio-economic problems in the form of lifestyles of representatives of different nationalities and ethnicities, not allowing the discrepancy issues to turn into a conflict.

4. Polytechnic society should promote the culture of inter-ethnic relations in everyday life in the form of solidarity among diverse ethnic groups, a single civilization mentality, and the formation of regional mentality, and the sustainable development of any society is directly related to this factor.

\section{Conclusion}

Thus, researching the theoretical foundations of interethnic relations on the basis of scientific and philosophical approach, promoting scientificallyconceptual views in this area, along with ensuring the development of our national science, serves to further enrich the concepts of international relations in the field of inter-ethnic relations, as well as the role of national science in scientific circles. This is very important in ensuring the positive nature of transformation processes in the context of the Central Asian poly-ethnic phenomena.

\section{References:}

1. (1987). Filosofsky Encyclopedicheskiy slovar. In: S. Averintseva, V.A. Arabogly and others. (Eds.). (p.640). Moscow.

2. Karimov, B. R. (2003). Nation, human, language: developmental problems. (p. 132, p.13). Karshi: Nasaf.

3. Drobijeva, L. M. (2003). Sotsialniye problem mejnatsionalnikh otnosheniy $\mathrm{v}$ post sovetskoyRossii. (p.188). Moscow: Tsentr obshchechelovecheskix tsennostey.

4. Otamuratov, S. (2005). The Philosophy of National Development. (p.368). Tashkent: “Academy" Publishing House.
5. Kuchkarov, V., \& Ernazarov, D. (2017). Democratization and national selfconsciousness. (p.100). Berlin: LAPLAMBERT Academic Publishing RU.

6. Pulatov, A. X. (1999). Democratic development and national relations. (p.212). Dushanbe, Irfon.

7. Choriev, S., \& Jumaev, A. (2002). National independence ideology and culture of interethnic relations. (p.32). Tashkent: Publishing House "Ijod Dunyo". 